\title{
THE WORLD NEEDS A NEW STRATEGY TO PROTECT THE PEOPLE OF HODEIDA AND AVOID CATASTROPHE
}

The Saudi- and UAE-led Coalition's assault on Hodeida - Yemen's lifeline port - threatens hundreds of thousands of civilians in that city, and around 20 million more who rely on its imports of food, fuel, medicine and other supplies. The strategy to prevent this assault through quiet diplomacy - by the Coalition's international partners including the US, UK and France - has failed. The UN Security Council has been largely silent, and has still not demanded an immediate end to the offensive. For the sake of millions of Yemenis, the time for a more effective strategy is now.

'People cannot move, jets are going around in the air all the time. I am just so afraid about the coming days. I do not know what will happen if our stock of food and water runs out, and the forces come into Hodeida.'

\section{- Oxfam female staff member trapped in Hodeida, 14 June 2018}

Even before this attack, Yemen was in a dire humanitarian situation after more than three years of war. Twentytwo out of 28 million Yemeni men, women and children require aid and protection, more than eight million people are at risk of famine, nearly half of all children aged between six months and five years old are chronically malnourished, and last year Yemen suffered the worst cholera outbreak ever recorded. Women struggle to access assistance and healthcare; they have experienced higher levels of malnutrition and insecurity because of a lack of electricity and fuel. Hodeida is the country's economic lifeline; other ports do not have the capacity to compensate for the loss of its ability to accommodate food and fuel shipments. If imports through Hodeida are disrupted, millions of people will either lose access to basic, critical commodities or no longer be able to afford them.

The attack is also likely to directly endanger the 600,000 people who live in and around the city - trapped, afraid, forced to flee, suffering shortages of food, water and supplies. UN Humanitarian Coordinator Lise Grande said that 'as many as 250,000 people may lose everything - even their lives.' ${ }^{1}$

The conflict in Yemen is a complex one, which has deepened over the last three years. The peace process was reinvigorated with the appointment of UN Special Envoy Martin Griffiths in March this year. In April, he was hopeful for peace and promised to propose a framework for negotiations within two months (recently suggested to be on 18 June). He stated that 'further military escalation will have serious consequences on the dire humanitarian situation in the country, and will have an impact on my efforts to resume political negotiations to reach an inclusive political settlement to the conflict in Yemen. I cannot overemphasize that there is no military solution to the conflict.'2

Yemen's neighbours have legitimate security concerns, but these can and should be accommodated through a political process instead of prolonged conflict and a battle likely to spark a catastrophic humanitarian crisis. This is a time to put the welfare and security of Yemenis, and the chance of peace, first. 


\section{URGENT ACTION NEEDED NOW}

Civilians will not be safe while the Saudi- and UAE-led Coalition's offensive on Hodeida and its battle with proHouthi forces there continues, regardless of any measures put in place to mitigate the risks. The only solution is for all Yemeni parties to return to a viable peace process, to negotiate a lasting, inclusive peace in good faith. The international community should exert every possible pressure on all parties to stop the bloodshed and engage in that meaningful peace process, supported by the UN Special Envoy. As part of this pressure, now more than ever it is time for the international community to suspend arms supplies to the parties in conflict.

The international calls to uphold international humanitarian law and maintain aid supplies are not an adequate alternative to an immediate ceasefire. But if this terrible conflict continues, all the warring parties' international partners should remember that - as parties to the Geneva Conventions - they have a duty to ensure respect for international humanitarian law, including an obligation to ensure respect for the law by their security partners. They should also ensure adherence to human rights law. And they should remember that the use of explosive weapons in populated areas tends to cause severe harm to individuals and communities, and damages vital infrastructure. Therefore:

- The UN Security Council and the Coalition's international partners should demand an immediate cessation of the assault and unconditional ceasefire by the Coalition and all Yemeni forces, including Houthi forces.

- Every relevant government should immediately suspend arms transfers to combatant parties in Yemen, and not grant future arms transfer licences until there is no longer a clear risk that arms could be used to commit serious violations or grave breaches of international human rights or humanitarian law.

- The UN Security Council and the international community should support an inclusive peace process, engaging Yemeni women, youth and civil society, and reflecting the international community's commitments to women, peace and security.

- The UN Security Council and the international community should ensure respect for international humanitarian law by the parties to Yemen's conflict, and ensure that Hodeida and Saleef remain fully operational and that food, fuel and other essential goods can move freely across the country.

- Allies of Saudi- and UAE-led Coalition members should leverage their relationships to avoid the use of any explosive weapons in populated areas in Hodeida.

- The conference planned in Paris on 27-28 June, to be co-chaired by Saudi Arabia, should be cancelled, unless the Hodeida offensive is halted. It would be entirely inappropriate to proceed with the conference under the present circumstances. Under no circumstances should France agree to co-host such a conference with a party to the conflict.

- The UN Security Council should urgently hold an open meeting, in which all governments' statements can be freely reported, to collectively demand the implementation of the above recommendations. Members of the Coalition and its international partners, including the US, UK and France, should not hide from public scrutiny behind closed doors at the Council, which has failed the people of Yemen for more than three years. 


\section{NOTES}

1 UN News. (2018, June 8). 250,000 people 'may lose everything - even their lives' in assault on key Yemeni port city: UN humanitarian coordinator. https://news.un.org/en/story/2018/06/1011701

2 United Nations Secretary-General. (2018, June 13). Note to Correspondents: Statement by Martin Griffiths, Special Envoy for Yemen on the situation in Hudaydah. https://www.un.org/sg/en/content/sg/note-correspondents/2018-06-13/notecorrespondents-statement-martin-griffiths-special 
This paper was written by Edmund Cairns and Debbie Hillier. It is part of a series of papers written to inform public debate on development and humanitarian policy issues.

For further information on the issues raised in this paper please email Dina Elmamoun:

delmamoun@oxfam.org.uk

This publication is copyright but the text may be used free of charge for the purposes of advocacy, campaigning, education, and research, provided that the source is acknowledged in full. The copyright holder requests that all such use be registered with them for impact assessment purposes. For copying in any other circumstances, or for re-use in other publications, or for translation or adaptation, permission must be secured and a fee may be charged. Email policyandpractice@oxfam.org.uk.

The information in this publication is correct at the time of going to press.

Published by Oxfam GB for Oxfam International under

ISBN 978-1-78748-283-8 in June 2018.

DOI: $10.21201 / 2018.2838$

Oxfam GB, Oxfam House, John Smith Drive, Cowley, Oxford, OX4 2JY, UK.

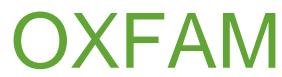

Oxfam is an international confederation of 20 organizations networked together in more than 90 countries, as part of a global movement for change, to build a future free from the injustice of poverty. Please write to any of the agencies for further information, or visit www.oxfam.org

Oxfam America (www.oxfamamerica.org)

Oxfam Australia (www.oxfam.org.au)

Oxfam-in-Belgium (www.oxfamsol.be)

Oxfam Brasil (www.oxfam.org.br)

Oxfam Canada (www.oxfam.ca)

Oxfam France (www.oxfamfrance.org)

Oxfam Germany (www.oxfam.de)

Oxfam GB (www.oxfam.org.uk)

Oxfam Hong Kong (www.oxfam.org.hk)

Oxfam IBIS (Denmark) (http://oxfamibis.dk/)
Oxfam India (www.oxfamindia.org)

Oxfam Intermón (Spain) (www.oxfamintermon.org)

Oxfam Ireland (www.oxfamireland.org)

Oxfam Italy (www.oxfamitalia.org)

Oxfam Japan (www.oxfam.jp)

Oxfam Mexico (www.oxfammexico.org)

Oxfam New Zealand (www.oxfam.org.nz)

Oxfam Novib (Netherlands) (www.oxfamnovib.nl)

Oxfam Québec (www.oxfam.qc.ca)

Oxfam South Africa (www.oxfam.org.za) 